\title{
Effect of Fermentation on the Protein Digestibility and Levels of Non-Nutritive Compounds of Pea Protein Concentrate
}

\section{Burcu Çabuk', Matthew \\ G. Nosworthy², Andrea \\ K. Stone', Darren R. \\ Korber', Takuji Tanaka', \\ James D. House ${ }^{2}$ and \\ Michael T. Nickerson ${ }^{1 *}$}

'Department of Food and Bioproduct Sciences, University of Saskatchewan,

51 Campus Dr., Saskatoon, SK, S7N

5A8, Canada

${ }^{2}$ Department of Human Nutritional

Sciences, Department of Food

Science, Department of Animal

Science, Canadian Centre for

Agri-Food Research in Health and

Medicine, Richardson Centre for

Functional Foods and Nutraceuticals,

University of Manitoba, Winnipeg,

MB, R3T 2N2, Canada

Received: 30 July 2017

Accepted: 28 February 2018
*Corresponding author:

Phone: +13069665030;

Fax: +13069668898;

Email:Michael.Nickerson@usask.ca

ORCID IDs: 0000-0001-8836-6047

(Çabuk), 0000-0002-3782-1035

(Nosworthy), 0000-0002-0918-1966

(Stone), 0000-0001-6350-209X (Korber), 0000-0003-3304-5830 (Tanaka), 0000-

-0003-1389-5491 (House) and 0000-

-0002-9040-5639 (Nickerson)

\section{SUMMARY}

In order to determine the impact of fermentation on protein quality, pea protein concentrate (PPC) was fermented with Lactobacillus plantarum for $11 \mathrm{~h}$ and total phenol and tannin contents, protease inhibitor activity, amino acid composition and in vitro protein digestibility were analyzed. Phenol levels, expressed as catechin equivalents (CE), increased on dry mass basis from 2.5 at $0 \mathrm{~h}$ to $4.9 \mathrm{mg}$ CE per $1 \mathrm{~g}$ of PPC at $11 \mathrm{~h}$. Tannin content rose from 0.14 at $0 \mathrm{~h}$ to a maximum of $0.96 \mathrm{mg}$ CE per $1 \mathrm{~g}$ of PPC after $5 \mathrm{~h}$, and thereafter declined to $0.79 \mathrm{mg} / \mathrm{g}$ after $11 \mathrm{~h}$. After $9 \mathrm{~h}$ of fermentation trypsin inhibitor activity decreased, however, at all other fermentation times similar levels to the PPC at time $0 \mathrm{~h}$ were produced. Chymotrypsin inhibitor activity decreased from 3.7 to 1.1 chymotrypsin inhibitory units (CIU) per mg following $11 \mathrm{~h}$ of fermentation. Protein digestibility reached a maximum (87.4 $\%$ ) after $5 \mathrm{~h}$ of fermentation, however, the sulfur amino acid score was reduced from 0.84 at $0 \mathrm{~h}$ to 0.66 at $11 \mathrm{~h}$. This reduction in sulfur content altered the in vitro protein digestibility-corrected amino acid score from $67.0 \%$ at $0 \mathrm{~h}$ to $54.6 \%$ at $11 \mathrm{~h}$. These data suggest that while fermentation is a viable method of reducing certain non-nutritive compounds in pea protein concentrate, selection of an alternative bacterium which metabolises sulfur amino acids to a lesser extent than $L$. plantarum should be considered.

Key words: pea protein concentrate, fermentation, non-nutritive compounds, protein digestibility, protein quality

\section{INTRODUCTION}

Pulses represent a nutritionally and economically viable protein source in developing countries where the consumption of animal proteins is scarce and expensive (1). In developed countries, pulses are often considered as alternative sources of protein, particularly as key ingredients in vegan foods. The classes of pulse crops include peas, chickpeas, lentils, faba beans and dry beans. Pulses contain significant quantities of proteins, carbohydrates and micronutrients, and are generally low in fat. With respect to amino acid content, pulses tend to have limited amount of thiol-containing amino acids (i.e. cysteine and methionine) and are rich in lysine compared to human nutritional requirements, whereas cereals have limited lysine content and high sulfur amino acid content (2). For this reason, pulse crops are often consumed alongside cereal grains as the two provide complementary amino acid profiles. Currently, the FAO/WHO defines protein quality in terms of the amino acid profile and digestibility of a protein source based on an in vivo bioassay (3). This definition of protein quality could be broadened further to include protein functionality, as in addition to their nutritional attributes, it is essential for protein ingredients to perform well in food product design.

Dehulling, soaking and thermal treatments (e.g. cooking) are often used in the preparation of pulses for human consumption. In addition to improving their palatability, cooking can reduce non-nutritive compounds that can have a negative effect on protein digestion and nutrient absorption. After cooking pulses for $3 \mathrm{~h}$, the methionine, tyrosine and threonine content of beans has been shown to decrease (4). Although not new technology, fermentation is re-gaining popularity as consumers seek out everyday foods with improved 
nutritional value, and can be used in either commercial/industrial environments or at the household level in developing countries as a means of improving food security. Fermentation has been used on pulses involving the raw seed (5-7), flour $(8-12)$ or protein isolates $(13,14)$. This may involve a solid-state batch fermentation or a submerged fermentation process involving protease-producing bacteria or fungi. Fermentation can improve the protein digestibility of pulses by reducing the levels of non-nutritive compounds that inhibit digestive enzymes (e.g. trypsin and chymotrypsin inhibitors) and promote protein crosslinking (e.g. phenolic and tannin compounds), as well as through the production of microbial proteases, which partially degrade and release some of the proteins from the matrix $(9,15,16)$. Hemalatha et al. $(17)$ reported that fermentation also improved mineral bioavailability, as microbial metabolism generates organic acids, which then form soluble complexes with mineral compounds preventing the formation of insoluble mineral-phytate complexes. In addition, fermentation can be employed with or without heating; thus it can bypass the loss of nutrients seen in cooking processes.

The overall goal of the present study is to examine the impact of Lactobacillus plantarum fermentation of pea protein concentrate on protein digestibility as well as the quantity and activity of certain non-nutritive compounds. While the recommended method for determining protein quality is a rodent bioassay (3), there is a tendency for reducing animal experimentation. For that reason, an in vitro method for determining protein digestibility, which has shown good correlation with in vivo values, was used (18). Pea protein is considered an emerging alternative to soy protein, due to it not being genetically modified and having lower allergenicity issues than soy. Development of technology for producing more nutritious fermented pea protein products is highly desirable by industry and the consumer.

\section{MATERIALS AND METHODS}

\section{Materials}

Pea protein concentrate (PPC) was kindly donated by Parrheim Foods (Saskatoon, SK, Canada), De Man, Rogosa, Sharpe (MRS) broth was purchased from Oxoid Co. (Nepean, ON, Canada), whereas all other chemicals used were of reagent grade and purchased from Thermo Fisher Scientific (Ottawa, ON, Canada). Water used in this research was produced using a Milli- ${ }^{\circledR}$ water purification system (Millipore, Etobicoke, ON, Canada). Lactobacillus plantarum NRRL B-4496 was obtained from the Agricultural Research Service Culture Collection, USDA (Peoria, IL, USA).

\section{Fermentation}

Fermentation of PPC ingredients was performed at $32^{\circ} \mathrm{C}$ over $11 \mathrm{~h}$ under anaerobic conditions using L. plantarum NRRL B-4496. In brief, L. plantarum cells were cultivated until the late exponential phase of growth (approx. $10 \mathrm{~h}$ ), collected by centrifugation (centrifuge model 5810R; Eppendorf, Mississauga, ON, Canada) at $10000 \times g$ for $20 \mathrm{~min}$ at $4{ }^{\circ} \mathrm{C}$, and then washed twice with sterile peptone solution. The resulting pellet was used to inoculate an Erlenmeyer flask containing $25 \%$ by mass per volume of PPC solution $(400 \mathrm{~mL})$, at a concentration of $7 \mathrm{log}$ CFU per $\mathrm{g}$ of PPC, and thereafter incubated under anaerobic conditions at $32^{\circ} \mathrm{C}$ for $11 \mathrm{~h}$. Anaerobic conditions were maintained by placing the experiments within a rectangular jar with AnaeroGen ${ }^{\mathrm{TM}}$ anaerobic gas-generating kits (Thermo Fisher Scientific, Miami, FL, USA). Aliquots (60 $\mathrm{mL}$ ) were taken at times $0,1,5,9$ and $11 \mathrm{~h}$ of fermentation, and then freeze-dried for $48 \mathrm{~h}$ using a freeze dryer (Labconco, FreeZone 12, Kansas City, MO, USA). All dried samples were then ground using a coffee grinder (Custom Grind ${ }^{\mathrm{TM}}$, model 80365; Hamilton Beach, Glen Allen, VA, USA) and stored under refrigeration temperature $\left(4^{\circ} \mathrm{C}\right)$ for further use. Fermentation experiments were run in triplicate, yielding three separately fermented PPC powders for each time point.

\section{Non-nutritive compounds}

\section{Trypsin inhibitory activity}

Trypsin inhibitory activity (TIA) was determined colorimetrically using an UV-visible spectrophotometer (Genesys ${ }^{\mathrm{TM}}$ 10S UV-Vis; Thermo Fisher Scientific, Wilmington, DE, USA) in accordance with the AACC International method 22-40.01 (19) with slight modification. In brief, $0.25 \mathrm{~g}$ of fermented sample was placed in a $50-\mathrm{mL}$ centrifuge tube to which $25 \mathrm{~mL}$ of 0.01 $\mathrm{M} \mathrm{NaOH}$ were added. Tubes were then vortexed for $1 \mathrm{~min}$ and stirred on a mechanical stirrer at 500 rpm (RT 5; IKA ${ }^{\oplus}$ Works Inc., Wilmington, NC, USA) for $3 \mathrm{~h}$. The mixture was centrifuged (model 5810R; Eppendorf) at $14000 \times g$ for $10 \mathrm{~min}$ at $4{ }^{\circ} \mathrm{C}$. Aliquots $(0,0.6,1.0,1.4$ and $1.8 \mathrm{~mL})$ of supernatant were then pipetted into test tubes and each volume was adjusted to 2.0 $\mathrm{mL}$ with Milli- ${ }^{\circledR}$ water. The tubes were then incubated with 2 $\mathrm{mL}$ of trypsin solution (4 mg of trypsin in $200 \mathrm{~mL}$ of $0.001 \mathrm{M}$ $\mathrm{HCl}$ ) for $5 \mathrm{~min}$ at $37^{\circ} \mathrm{C}$ in a water bath. A volume of $5 \mathrm{~mL}$ of prewarmed substrate solution ( $40 \mathrm{mg}$ of $\mathrm{N}$ - $\mathrm{a}$-benzoyl-D, $\mathrm{L}$-arginine 4-nitroanilide hydrochloride (D,L-BAPNA) dissolved with $1 \mathrm{~mL}$ of dimethyl sulfoxide, then diluted to $100 \mathrm{~mL}$ with Tris- $\mathrm{HCl}$ buffer (0.05 M, pH=8.2)) was added into each test tube to initiate the reaction. The reaction was stopped by the addition of $1 \mathrm{~mL}$ of acetic acid after exactly $10 \mathrm{~min}$. The mixed solution was then filtered through Whatman no. 2 filter paper (GE Healthcare UK Limited, Buckinghamshire, UK). One trypsin inhibitory unit (TIU) was equivalent to an increase of 0.01 absorbance unit at $410 \mathrm{~nm}$ per $10 \mathrm{~mL}$ of reaction mixture compared to the blank sample (addition of trypsin solution after acetic acid). Trypsin inhibitor activity (TIA) was defined as the number of trypsin units inhibited per mg of sample and expressed in trypsin inhibitory units (TIU) per mg of dry sample, calculated using the following equation (20):

$$
\mathrm{TIA}=\frac{\mathrm{TIU}}{V_{1}} \cdot \frac{V_{2}}{m(\text { sample })} \cdot \mathrm{D} \cdot \frac{100}{100-\mathrm{MC}}
$$


where $V_{1}$ is the volume of extract taken in $\mathrm{mL}, V_{2}=25 \mathrm{~mL}$ of extract, $m$ (sample) $=500 \mathrm{mg}, \mathrm{D}$ is the dilution factor and $\mathrm{MC}$ is the moisture content of PPC samples. The trypsin inhibitor extract was diluted to fall within $40-60 \%$ of trypsin inhibition at $1 \mathrm{~mL}$.

\section{Chymotrypsin inhibitory activity}

Chymotrypsin inhibitory activity (CIA) was assayed according to the method described by Makkar et al. (21) with the following modifications. A mass of $1 \mathrm{~g}$ of PPC sample was placed in a $50-\mathrm{mL}$ centrifuge tube to which $10 \mathrm{~mL}$ of borate buffer $(0.1 \mathrm{M}, \mathrm{pH}=7.6)$ were added and vortexed for $1 \mathrm{~min}$. The mixture was then stirred on a mechanical stirrer at $500 \mathrm{rpm}$ for $1 \mathrm{~h}$. The slurry was centrifuged at $3000 \times \mathrm{g}$ (model 5810R; Eppendorf) for $10 \mathrm{~min}$ at $4{ }^{\circ} \mathrm{C}$. In test tubes, 0, 0.25, 0.5 and $0.75 \mathrm{~mL}$ of the extract were added and diluted to $1 \mathrm{~mL}$ with borate buffer. These mixtures were incubated with $1 \mathrm{~mL}$ of stock chymotrypsin solution containing $4 \mathrm{mg}$ of chymotryp$\sin$ in $100 \mathrm{~mL}$ of $0.001 \mathrm{M} \mathrm{HCl}$ at $37^{\circ} \mathrm{C}$ for $10 \mathrm{~min}$. Next, $2 \mathrm{~mL}$ of pre-warmed casein solution ( $1 \%$, by mass per volume) in borate buffer at $\mathrm{pH}=7.6$ were added, samples were mixed and incubated at $37^{\circ} \mathrm{C}$ for $10 \mathrm{~min}$. The reaction was then stopped by the addition of $6 \mathrm{~mL}$ of trichloroacetic acid reagent (containing $18 \mathrm{~g}$ of trichloroacetic acid, $18 \mathrm{~g}$ of anhydrous sodium acetate and $20 \mathrm{~mL}$ of glacial acetic acid and diluted up to $1 \mathrm{~L}$ with distilled water). The suspension was held at room temperature for at least $30 \mathrm{~min}$ and then filtered using Whatman no. 2 filter paper. The absorbance of the filtrate was recorded at $275 \mathrm{~nm}$ using a Genesys ${ }^{\mathrm{TM}} 10 \mathrm{~S}$ UV-Vis spectrophotometer (Thermo Fisher Scientific) against the appropriate blank. A blank contained $6 \mathrm{~mL}$ of trichloroacetic acid reagent and 2 $\mathrm{mL}$ of casein solution. One chymotrypsin unit was defined as an increase of 0.01 absorbance unit at $275 \mathrm{~nm}$ of the reaction mixture. Chymotrypsin inhibitory activity is defined as the number of inhibited chymotrypsin units and the results are expressed in chymotrypsin inhibitory units (CIU) per milligram of the sample, and calculated using the following equation:

$$
\mathrm{CIA}=\frac{\mathrm{CIU}}{V_{1}} \cdot \frac{V_{2}}{m(\text { sample })} \cdot \mathrm{D} \cdot \frac{100}{100-\mathrm{MC}}
$$

where $V_{1}$ is the volume of extract taken in $\mathrm{mL}, V_{2}=10 \mathrm{~mL}$ of extract, $m$ (sample) $=1000 \mathrm{mg}, \mathrm{D}$ is the dilution factor, and MC is the moisture content of PPC samples.

\section{Total phenolic content}

The total phenolic content in the fermented samples was determined using the Folin-Ciocalteu assay according to Waterman and Mole (22). Briefly, $1 \mathrm{~g}$ of sample was extracted with $15 \mathrm{~mL}$ of solvent ( $1 \% \mathrm{HCl}$ in methanol) for $2 \mathrm{~h}$, and then centrifuged for $10 \mathrm{~min}$ at $1510 \times \mathrm{g}$ (model 5810R; Eppendorf) and $25^{\circ} \mathrm{C}$. The resulting supernatant was decanted and kept in a different tube. A volume of $5 \mathrm{~mL}$ of solvent was again added to the residue after removal of supernatant and vortexed every 5 min for 20 min, centrifuged (as above) and the supernatant was removed. This procedure was repeated once more, and all three supernatants were then pooled. A 0.5-mL aliquot of the extract from the pooled supernatants was then mixed with $2.5 \mathrm{~mL}$ of Folin-Ciocalteu reagent. The solution was kept at $25^{\circ} \mathrm{C}$ for $5-8$ min before adding $7.5 \mathrm{~mL}$ of sodium carbonate solution (20\%, by mass per volume) and adjusting the volume to $50 \mathrm{~mL}$ with Milli- $Q^{\circledR}$ water. After $2 \mathrm{~h}$, the absorbance was measured at 760 nm using a Genesys ${ }^{\mathrm{TM}} 10 \mathrm{~S}$ UV-Vis spectrophotometer (Thermo Fisher Scientific). Catechin (0-1 mg/mL) was used as a standard for the calibration curve. The total phenolic content was expressed in mg of catechin equivalents (CE) per $1 \mathrm{~g}$ of dry matter.

\section{Total tannins}

Tannins were quantified as the difference between the total phenols before and after tannin removal from the extract using insoluble polyvinylpolypyrrolidone (PVPP) according to the method of Makkar et al. (23). In brief, $1 \mathrm{~mL}$ of extract was mixed with $100 \mathrm{mg}$ of PVPP. After vortexing, the extract was left for $15 \mathrm{~min}$ at $4{ }^{\circ} \mathrm{C}$ and then centrifuged at $1110 \times g$ (model 5810R; Eppendorf) for $10 \mathrm{~min}$. The supernatant was then used to determine the phenolic content (having no tannin) as performed by the aforementioned method. The tannin content was determined as the difference between the total phenolic content before and after precipitation with PVPP.

\section{Protein quality}

\section{Amino acid analysis}

Amino acid analysis was carried out on PPC from one fermentation run at POS Bio-Sciences Corp. (Saskatoon, SK, Canada) utilizing acid/heat hydrolysis followed by quantification using chromatographic techniques. In brief, approx. $20 \mathrm{mg}$ of each protein concentrate sample were weighed into separate $20 \times 150 \mathrm{~mm}$ screw cap Pyrex ${ }^{\circledast}$ tubes containing $15 \mathrm{~mL}$ of $6 \mathrm{M}$ $\mathrm{HCl}$. Each tube was then flushed with $\mathrm{N}_{2}$ gas. The tubes were then capped and placed into an oven at $110^{\circ} \mathrm{C}$ for $20 \mathrm{~h}$. After acid hydrolysis, the individual amino acids were quantified by high-performance liquid chromatography using the Pico Tag amino acid analysis system (Waters Corporation, Milford, MA, USA) (24-26). The amino acid score was calculated as the ratio of individual amino acids in $1 \mathrm{~g}$ of PPC to the FAO/WHO/UNU recommended reference protein (27). The amino acid composition of the reference protein was as follows (amino acid in $\mathrm{mg}$ per $g$ of protein): histidine 19 , isoleucine 28 , leucine 66 , lysine 58 , methionine+cysteine 25 , phenylalanine+tyrosine 63 , threonine, 34, tryptophan 11 and valine 35. The amino acid score of the protein concentrate was the lowest ratio value among the 18 amino acids.

In vitro protein digestibility and in vitro protein digestibility-corrected amino acid score

The in vitro protein digestibility (IVPD) was determined by the $\mathrm{pH}$ drop of the solution after digestion by a multi-enzyme solution $(28,29)$. This solution was prepared fresh daily by mixing $31 \mathrm{mg}$ of chymotrypsin (bovine pancreas $\geq 40$ units per mg 
of protein), $16 \mathrm{mg}$ of trypsin (porcine pancreas $13000-20000$ BAEE units per mg of protein) and $13 \mathrm{mg}$ of protease (Streptomyces griseus $\geq 15$ units $/ \mathrm{mg}$ solid) in $10 \mathrm{~mL}$ Milli-Q ${ }^{\circledR}$ water and kept at $37{ }^{\circ} \mathrm{C}$ and $\mathrm{pH}$ adjusted to 8.0 using $0.1 \mathrm{M} \mathrm{NaOH}$ and $\mathrm{HCl}$. Approximately $155.9 \mathrm{mg}$ of PPC (to meet $62.5 \mathrm{mg}$ protein in $10 \mathrm{~mL}$ of water) was mixed with $10 \mathrm{~mL}$ of pre-warmed Milli- $Q^{\circledR}$ water in a 50-mL beaker. The mixture was stirred for $1 \mathrm{~h}$ at $37^{\circ} \mathrm{C}$, and $\mathrm{pH}$ adjusted to 8.0 using $0.1 \mathrm{M} \mathrm{NaOH}$ and $\mathrm{HCl}$ before adding $1 \mathrm{~mL}$ of the multi-enzyme solution. The $\mathrm{pH}$ of the protein solution was recorded every $30 \mathrm{~s}$ for $10 \mathrm{~min}$ and the in vitro protein digestibility (IVPD) was calculated using the following equation:

$$
\text { IVPD }=65.66+18.10 \cdot \Delta \mathrm{pH}_{10 \mathrm{~min}}
$$

where $\Delta \mathrm{pH}_{10 \text { min }}$ refers to the change in $\mathrm{pH}$ from initial 8.0 to the end of $10 \mathrm{~min}$. The in vitro protein digestibility-corrected amino acid score (IVPDCAAS) was calculated as the product of the amino acid score and in vitro protein digestibility.

\section{Statistical analysis}

A one-way ANOVA with Tukey's post-hoc test was used to detect statistical differences in response to fermentation time of protein quality data (IVPD and IVPDCAAS) and for the non-nutritive compounds. All statistical analyses were performed with Systat v. 10 software (30).

\section{RESULTS AND DISCUSSION}

\section{Effect of fermentation on the levels of non-nutritive compounds}

Non-nutritive compounds that are known to negatively impact protein quality such as the presence of trypsin and chymotrypsin inhibitors, as well as total phenolics and tannins (31-33) were examined as a function of fermentation time and are reported in Table 1 . Trypsin inhibitory activity (TIA) of unfermented PPC ( $t=0 \mathrm{~h}$ ) was $2.3 \mathrm{TIU} / \mathrm{mg}$ and was in the range of what has been reported for pea (Pisum sativum L.) (2.22-7.66 TIU/mg) (34). After $9 \mathrm{~h}$ of fermentation, TIA reached a low (1.1 TIU/mg) value and was significantly different from $t=0 \mathrm{~h}(\mathrm{p}<0.01)$. Chandra-Hioe et al. (16) reported no significant change in TIA values after $16 \mathrm{~h}$ of fermentation of chickpea (desi/kabuli) and faba bean flour. Starzyńska-Janiszewska and
Stodolak (35) found that solid-state fermentation of grass pea flour resulted in a $99 \%$ reduction in TIA levels. Reduction in TIA values was also reported by Coda et al. (36) of faba bean flour by L. plantarum VTT E-133328. The chymotrypsin inhibitory activity (CIA) of PPC as a function of fermentation time is given in Table 1. In contrast to the TIA, CIA continuously declined over the 11-hour fermentation process $(p<0.01)$. At $t=0 \mathrm{~h}$, the PPC had $3.7 \mathrm{CIU} / \mathrm{mg}$ but this decreased to $1.9 \mathrm{CIU} /$ mg after $1 \mathrm{~h}$ of fermentation, a reduction of $49 \%$. The CIA values proceeded to decrease until reaching $1.1 \mathrm{CIU} / \mathrm{mg}$ after the 11-hour fermentation time course.

Phenolic compounds (including tannins) cross-link proteins, making them less susceptible to enzyme action during digestion. The total phenolic and tannin levels of PPC, as a function of fermentation time, are given in Table 1. A one-way ANOVA found that the effect of fermentation time on the level of total phenolic content was significant $(p<0.01)$. At $t=0 \mathrm{~h}$, total phenolic content expressed as catechin equivalent (CE) mass fraction on a dry mass basis was $2.5 \mathrm{mg}$ per $\mathrm{g}$ of PPC, which then continually increased over the 11-hour fermentation period to a final level of $4.9 \mathrm{mg}$ per $\mathrm{g}$ of PPC. This increase may be due to the release of soluble phenolic compounds as polymeric phenolics are degraded during fermentation $(37,38)$. It is also likely that loosening of the lignocellulosic matrix via fermentation liberates phenolic compounds from an inaccessible state. The effects of fermentation on total phenolic content in different legumes have been reported in several previous studies. For instance, Starzyńska-Janiszewska and Stodolak (35) reported total phenolic content of grass pea flour to increase after $24 \mathrm{~h}$ of fermentation with L. plantarum and that a higher percent inoculum resulted in a higher amount of total phenolics. Fernandez-Orozco et al. (39) also observed that fermentation with L. plantarum increased total phenolic levels by approx. $200 \%$ in soybean flour and by approx. $310 \%$ when the soybean flour was naturally fermented. Additionally, a Bacillus subtilis-based solid-state fermentation significantly increased the phenolic content of kidney beans by 96 and $126 \%$ after 48 and 96 h, respectively (40). Overall, the total tannin levels significantly increased from approx. $0.14 \mathrm{mg} / \mathrm{g}$ at $t=0 \mathrm{~h}$ to a maximum of approx. $0.96 \mathrm{mg} / \mathrm{g}$ after $5 \mathrm{~h}$, and then declined to approx. $0.79 \mathrm{mg} / \mathrm{g}$ after $11 \mathrm{~h}$. The increase was likely caused by the same factors that affected the phenolic content increase, e.g. liberation from the lignocellulosic matrix. The observed decrease in tannin levels after

Table 1. Non-nutritive content on a dry mass basis of pea protein concentrate fermented for different times with L. plantarum

\begin{tabular}{ccccc}
$t($ fermentation $) / \mathrm{h}$ & $w($ total phenol)*/(mg/g) & $w(\text { tannin })^{*} /(\mathrm{mg} / \mathrm{g})$ & $\mathrm{CIA} /(\mathrm{CIU} / \mathrm{mg})$ & $\mathrm{TIA} /(\mathrm{TIU} / \mathrm{mg})$ \\
0 & $(2.5 \pm 0.3)^{\mathrm{a}}$ & $(0.14 \pm 0.04)^{\mathrm{a}}$ & $(3.7 \pm 0.2)^{\mathrm{a}}$ & $(2.3 \pm 0.0)^{\mathrm{ab}}$ \\
1 & $(3.1 \pm 0.2)^{\mathrm{ab}}$ & $(0.41 \pm 0.06)^{\mathrm{ab}}$ & $(1.9 \pm 0.4)^{\mathrm{b}}$ & $(2.6 \pm 0.2)^{\mathrm{a}}$ \\
5 & $(3.9 \pm 0.5)^{\mathrm{bc}}$ & $(0.96 \pm 0.19)^{\mathrm{c}}$ & $(1.7 \pm 0.3)^{\mathrm{bc}}$ & $(1.9 \pm 0.1)^{\mathrm{b}}$ \\
9 & $(4.7 \pm 0.3)^{\mathrm{c}}$ & $(0.55 \pm 0.16)^{\mathrm{abc}}$ & $(1.7 \pm 0.3)^{\mathrm{bc}}$ & $(1.1 \pm 0.0)^{\mathrm{c}}$ \\
11 & $(4.9 \pm 0.4)^{\mathrm{c}}$ & $(0.79 \pm 0.16)^{\mathrm{bc}}$ & $(1.1 \pm 0.5)^{\mathrm{c}}$ & $(1.9 \pm 0.1)^{\mathrm{b}}$ \\
\hline
\end{tabular}

*Expressed as catechin equivalent $(\mathrm{mg})$ on a dry mass basis. Data represent the mean value \pm standard deviation $(\mathrm{N}=3)$. Data with different superscript letters in the same column indicate significant differences $(p<0.01)$. TIA=trypsin inhibitory activity defined as the number of trypsin units (TIU) inhibited per $\mathrm{mg}$ of sample, $\mathrm{CIA}=$ chymotrypsin inhibitory activity defined as the number of chymotrypsin inhibitory units (CIU) per mg of sample 
5 to $9 \mathrm{~h}$ of fermentation may be related with an increase in tannase activity by $L$. plantarum during fermentation $(41,42)$. Ramachandran et al. (6) and Onwurafor et al. (10) reported a decrease in total tannin content after fermentation of grass pea seed meal and mung bean flour, respectively.

\section{Effect of fermentation on protein quality}

The amino acid composition (in $\mathrm{g} / 100 \mathrm{~g}$ sample) of PPC and fermented PPC is given in Table 2. All amino acid mass fractions increased with fermentation time except arginine and tryptophan, which remained similar. To calculate the amino acid score, the amino acid composition (in $\mathrm{mg}$ per $\mathrm{g}$ protein) must be compared to the recommended FAO/WHO amino acid requirements (3) (Table 3 ). Each essential amino acid mass fraction declined with fermentation time when reported in mg per $\mathrm{g}$ of protein ( $v s$. per $\mathrm{g}$ of sample). While both tryptophan and the sulfur amino acids (SAA) were limiting, when compared to the reference pattern, the SAA had lower scores at all fermentation times investigated. This is similar to previous findings where pea protein was first limiting in SAA (2). During fermentation, the reduction in SAA content resulted in the amino acid score changing from 0.84 at $0 \mathrm{~h}$ to 0.66 at $11 \mathrm{~h}$ (Table 3).

Table 2. Amino acid (AA) composition of pea protein concentrate as a function of fermentation time, and of the bacterial pellet (BP)

\begin{tabular}{|c|c|c|c|c|c|c|}
\hline \multirow{3}{*}{$\mathrm{AA}$} & \multicolumn{6}{|c|}{$w(\mathrm{AA}) /(\mathrm{g} / 100 \mathrm{~g})$} \\
\hline & \multicolumn{6}{|c|}{$t($ fermentation $) / \mathrm{h}$} \\
\hline & 0 & 1 & 5 & 9 & 11 & $\mathrm{BP}$ \\
\hline \multicolumn{7}{|l|}{ Essential } \\
\hline Cysteine & 0.47 & 0.51 & 0.50 & 0.44 & 0.44 & 0.14 \\
\hline Histidine & 1.06 & 1.14 & 1.20 & 1.18 & 1.09 & 0.42 \\
\hline Isoleucine & 1.79 & 1.80 & 1.90 & 1.87 & 1.88 & 0.62 \\
\hline Leucine & 3.40 & 3.37 & 3.59 & 3.51 & 3.56 & 0.92 \\
\hline Lysine & 3.33 & 3.90 & 3.45 & 3.42 & 3.51 & 0.94 \\
\hline Methionine & 0.37 & 0.37 & 0.37 & 0.42 & 0.35 & 0.22 \\
\hline Phenylalanine & 2.26 & 2.24 & 2.39 & 2.35 & 2.40 & 0.48 \\
\hline Threonine & 1.73 & 1.88 & 1.92 & 1.86 & 1.81 & 0.51 \\
\hline Tryptophan & 0.41 & 0.41 & 0.42 & 0.41 & 0.42 & 0.12 \\
\hline Valine & 2.03 & 2.08 & 2.13 & 2.19 & 2.19 & 0.77 \\
\hline \multicolumn{7}{|l|}{ Non-essential } \\
\hline Alanine & 1.97 & 2.01 & 2.14 & 2.08 & 2.09 & 1.21 \\
\hline Arginine & 3.81 & 3.87 & 4.10 & 3.97 & 3.90 & 0.76 \\
\hline Aspartic acid & 5.40 & 5.70 & 5.88 & 5.78 & 5.68 & 1.33 \\
\hline Glutamic acid & 7.96 & 8.41 & 8.69 & 8.54 & 8.40 & 1.69 \\
\hline Glycine & 2.02 & 2.10 & 2.17 & 2.14 & 2.14 & 0.84 \\
\hline Proline & 2.03 & 2.05 & 2.24 & 2.11 & 2.12 & 0.81 \\
\hline Serine & 2.59 & 2.75 & 2.83 & 2.77 & 2.72 & 0.64 \\
\hline Tyrosine & 1.53 & 1.61 & 1.68 & 1.65 & 1.63 & 0.40 \\
\hline
\end{tabular}

In vitro protein digestibility (IVPD) of all samples showed no obvious trend, with digestibility values ranging from approx. 80 to $87 \%$ depending on the fermentation time (Table 4). Chandra-Hioe et al. (16) found that desi chickpea flour fermented with a lyophilized yogurt culture (containing Lactobacillus delbrueckii ssp. bulgaricus and Streptococcus
Table 3. Essential amino acid (AA) mass fraction and score of pea protein concentrate as a function of fermentation time, and of the bacterial pellet (BP)

\begin{tabular}{|c|c|c|c|c|c|c|c|c|c|}
\hline \multirow{3}{*}{$\begin{array}{l}\text { t(fermenta- } \\
\text { tion)/h }\end{array}$} & \multicolumn{9}{|c|}{$A A$} \\
\hline & \multicolumn{4}{|c|}{ MET+ } & \multirow{2}{*}{\multicolumn{2}{|c|}{$\begin{array}{cc}\text { PHE + } \\
\text { LEU TRY }\end{array}$}} & \multirow[b]{2}{*}{ HIS } & \multirow{3}{*}{ LYS } & \multirow[b]{2}{*}{ TRP } \\
\hline & THR & VAL & CYS & ILE & & & & & \\
\hline \multicolumn{9}{|c|}{$w($ essential amino acid $) /(\mathrm{mg} / \mathrm{g})$} & \\
\hline 0 & 43 & 51 & 21 & 45 & 85 & 95 & 26 & 83 & 10 \\
\hline 1 & 44 & 48 & 21 & 42 & 79 & 90 & 27 & 91 & 10 \\
\hline 5 & 41 & 46 & 19 & 41 & 77 & 87 & 26 & 74 & 9 \\
\hline 9 & 40 & 47 & 19 & 40 & 76 & 86 & 25 & 74 & 9 \\
\hline 11 & 38 & 46 & 16 & 39 & 74 & 84 & 23 & 73 & 9 \\
\hline $\mathrm{BP}$ & 23 & 34 & 16 & 28 & 41 & 39 & 19 & 42 & 5 \\
\hline $\begin{array}{l}\text { Reference } \\
\text { pattern (3) }\end{array}$ & 34 & 35 & 25 & 28 & 66 & 63 & 19 & 58 & 11 \\
\hline \multicolumn{10}{|c|}{ AA score } \\
\hline 0 & 1.27 & 1.45 & $0.84^{*}$ & 1.59 & 1.28 & 1.50 & 1.39 & 1.43 & 0.93 \\
\hline 1 & 1.29 & 1.39 & $0.82^{*}$ & 1.50 & 1.19 & 1.42 & 1.40 & 1.57 & 0.87 \\
\hline 5 & 1.21 & 1.31 & $0.75^{*}$ & 1.46 & 1.17 & 1.39 & 1.36 & 1.28 & 0.82 \\
\hline 9 & 1.18 & 1.35 & $0.74^{*}$ & 1.44 & 1.15 & 1.37 & 1.34 & 1.27 & 0.80 \\
\hline 11 & 1.11 & 1.30 & $0.66^{*}$ & 1.40 & 1.12 & 1.33 & 1.19 & 1.26 & 0.79 \\
\hline $\mathrm{BP}$ & 0.67 & 0.98 & 0.64 & 0.98 & 0.62 & 0.62 & 0.98 & 0.72 & $0.48^{*}$ \\
\hline
\end{tabular}

*Indicates the first limiting amino acid. Data represent the mean value of one processing run. $\mathrm{THR}=$ threonine, $\mathrm{VAL}=$ valine, $\mathrm{MET}=$ methionine, $\mathrm{CYS}=$ cysteine, ILE=isoleucine, LEU=leucine, $\mathrm{PHE}=$ phenylalanine, TYR=tyrosine, HIS=histidine, LYS=lysine and TRP=tryptophan

Table 4. In vitro protein digestibility of fermented pea protein concentrate as a function of fermentation time, and of the bacterial pellet (BP)

\begin{tabular}{cccc}
$\begin{array}{c}t(\text { fermenta- } \\
\text { tion) } / \mathrm{h}\end{array}$ & $\begin{array}{c}\text { AA score } \\
\text { (of the limit- } \\
\text { ing AA) }\end{array}$ & IVPD/\% & IVPDCAAS/\% \\
0 & 0.84 & $(80.0 \pm 1.5)^{\mathrm{b}}$ & $(67.0 \pm 1.2)^{\mathrm{a}}$ \\
1 & 0.82 & $(81.1 \pm 0.5)^{\mathrm{bc}}$ & $(66.6 \pm 0.4)^{\mathrm{a}}$ \\
5 & 0.75 & $(87.4 \pm 1.0)^{\mathrm{d}}$ & $(65.2 \pm 0.8)^{\mathrm{a}}$ \\
9 & 0.74 & $(83.4 \pm 0.5)^{\mathrm{c}}$ & $(61.9 \pm 0.4)^{\mathrm{b}}$ \\
11 & 0.66 & $(83.2 \pm 0.2)^{\mathrm{c}}$ & $(54.6 \pm 0.1)^{\mathrm{c}}$ \\
BP & 0.48 & $(69.6 \pm 0.7)^{\mathrm{a}}$ & $(33.2 \pm 0.3)^{\mathrm{d}}$ \\
\hline
\end{tabular}

Data represent the mean value \pm standard deviation $(N=3)$. Data with different superscript letters in the same column indicate significant differences $(p<0.01)$

thermophilus) showed improved IVPD where values increased from appox. 70.5 to $77.2 \%$, whereas IVPD of kabuli chickpea and faba bean flours remained unchanged. The authors suggested that the rise in IVPD may be due to a reduction in protein cross linking induced by the presence of non-nutritive compounds (e.g. phenolics and tannins), making them more susceptible to proteolytic attack. Improved IVPD was also reported in fermented grass pea flour coinciding with a $99 \%$ reduction in TIA levels (43). In the present study, the alteration of SAA content resulted in a reduced IVPDCAAS as a function of fermentation time, from $67.0 \%$ at $t=0 \mathrm{~h}$ to approx. $54.6 \%$ after $11 \mathrm{~h}$ of fermentation (Table 4). This could be due to either: (i) a dilution effect caused by the approx. $16 \%$ rise in 
total protein from the bacterial biomass (total protein levels increased on a dry mass basis from 40 to $48 \%$ during the 11 hour fermentation time course, data not shown), (ii) the bacterial biomass protein was of lower quality than the pea as the IVPDCAAS for the bacterial pellet was $33.2 \%$ (Table 4), and (iii) the thiol amino acids were metabolized by the bacteria to produce volatiles (44).

\section{CONCLUSION}

Lactobacillus plantarum fermentation of PPC influenced the non-nutritive compounds while causing a decrease in protein quality. Phenol and tannin content increased with fermentation whereas the inhibitory digestive enzyme activity decreased. Although protein digestibility was increased, the alteration of sulfur amino acid content resulted in an overall reduction in protein quality. These results indicate that while fermentation is a viable method for reducing levels of non-nutritive compounds and improving protein digestibility of PPC, exploration of an alternative bacteria which metabolise sulfur amino acids to a lesser extent than L. plantarum is necessary. Furthermore, optimization studies of fermentation conditions may offer a different outcome than found in the present study. Fermentation of pulse protein concentrates by yeast may also offer some alternative insights for future directions. To date, little work has been done on improving the nutritional value of pulse protein concentrates, however, the present study shows potential and warrants further investigation with other bacterial, fungal or yeast inocula to better understand mechanisms for enhancing their nutritional value.

\section{ACKNOWLEDGEMENTS}

Financial support for this research was provided by the Global Institute for Food Security at the University of Saskatchewan (Saskatoon, SK, Canada) and the Saskatchewan Ministry of Agriculture Development Fund (ADF\#: 2014-0283).

\section{REFERENCES}

1. Multari S, Stewart D, Russell WR. Potential of fava bean as future protein supply to partially replace meat intake in the human diet. Compr Rev Food Sci Food Saf. 2015;14(5):511-22. https://doi.org/10.1111/1541-4337.12146

2. Sarwar G, Peace RW. Comparisons between true digestibility of total nitrogen and limiting amino acids in vegetable proteins fed to rats. J Nutr. 1986;116(7):1172-84. https://doi.org/10.1093/jn/116.7.1172

3. FAO/WHO. Protein quality evaluation: Report of the joint FAO/WHO expert consultation. Rome, Italy: Food and Agriculture Organization of the United Nations and World Health Organization (FAO/WHO); 1991. Available from: http://www.fao.org/ag/humannutrition/35978-02317b97 9a686a57aa4593304ffc17f06.pdf.

4. Candela M, Astiasaran I, Bello J. Cooking and warm-holding: Effect on general composition and amino acids of kidney beans (Phaseolus vulgaris), chickpeas (Cicer arietinum), and lentils (Lens culinaris). J Agric Food Chem. 1997;45(12):4763-67.

https://doi.org/10.1021/jf9702609

5. Yigzaw Y, Gorton L, Solomon T, Akalu G. Fermentation of seeds of teff (Eragrostis teff), grass-pea (Lathyrus sativus), and their mixtures: Aspects of nutrition and food safety. J Agric Food Chem. 2004;52(5):1 163-69.

https://doi.org/10.1021/jf034742y

6. Ramachandran S, Bairagi A, Ray AK. Improvement of nutritive value of grass pea (Lathyrus sativus) seed meal in the formulated diets for rohu, Labeo rohita (Hamilton) fingerlings after fermentation with a fish gut bacterium. Bioresour Technol. 2005;96(13):1465-72.

https://doi.org/10.1016/j.biortech.2004.12.002

7. Torino MI, Limón RI, Martínez-Villaluenga C, Mäkinen S, Pihlanto A, Vidal-Valverde C, Frias J. Antioxidant and antihypertensive properties of liquid and solid state fermented lentils. Food Chem. 2013;136 (2):1030-37.

https://doi.org/10.1016/j.foodchem.2012.09.015

8. Elyas SHA, El Tinay AH, Yousif NE, Elsheikh EAE. Effect of natural fermentation on nutritive value and in vitro protein digestibility of pearl millet. Food Chem. 2002;78(1):75-9. https://doi.org/10.1016/S0308-8146(01)00386-7

9. Reyes-Moreno C, Cuevas-Rodríguez EO, Milán-Carrillo J, Cárdenas-Valenzuela OG, Barrón-Hoyos J. Solid state fermentation process for producing chickpea (Cicer arietinum L) tempeh flour. Physicochemical and nutritional characteristics of the product. J Sci Food Agric. 2004;84(3):271-78. https://doi.org/10.1002/jsfa.1637

10. Onwurafor EU, Onweluzo JC, Ezeoke AM. Effect of fermentation methods on chemical and microbial properties of mung bean (Vigna radiata) flour. Niger Food J. 2014;32(1):89-96.

https://doi.org/10.1016/S0189-7241(15)30100-4

11. Klupsaite D, Juodeikiene G, Zadeike D, Bartkiene E, Maknickiene $Z$, Liutkute $G$. The influence of lactic acid fermentation on functional properties of narrow-leaved lupine protein as functional additive for higher value wheat bread. LWT Food Sci Technol. 2017;75:180-6. https://doi.org/10.1016/j.lwt.2016.08.058

12. Chawla P, Bhandari L, Sadh PK, Kaushik R. Impact of solid state fermentation (Aspergillus oryzae) on functional properties and mineral bioavailability of black eyed pea (Vigna unguiculata) seed flour. Cereal Chem. 2017;94(3):437-42. https://doi.org/10.1094/CCHEM-05-16-0128-R

13. Meinlschmidt $P$, Schweiggert-Weisz $U$, Eisner P. Soy protein hydrolysates fermentation: Effect of debittering and degradation of major soy allergens. LWT - Food Sci Technol. 2016;71:202-12.

https://doi.org/10.1016/j.lwt.2016.03.026

14. Meinlschmidt P, Ueberham E, Lehmann J, Schweiggert-Weisz $\mathrm{U}$, Eisner P. Immunoreactivity, sensory and physicochemical 
properties of fermented soy protein isolate. Food Chem. 2016;205:229-38.

https://doi.org/10.1016/j.foodchem.2016.03.016

15. Shekib, LA. Nutritional improvement of lentils, chick pea rice and wheat by natural fermentation. Plant Foods Hum Nutr. 1994;46(3):201-5. https://doi.org/10.1007/BF01088991

16. Chandra-Hioe MV, Wong CHM, Arcot J. The potential use of fermented chickpea and faba bean flour as food ingredients. Plant Foods Hum Nutr. 2016;7(1)1:90-5. https://doi.org/10.1007/s11130-016-0532-y

17. Hemalatha S, Platel K, Srinivasan K. Influence of germination and fermentation on bioaccessibility of zinc and iron from food grains. Eur J Clin Nutr. 2006;61:342-48. https://doi.org/10.1038/sj.ejcn.1602524

18. Nosworthy MG, Neufeld J, House JD. Determination of the in vivo and in vitro protein quality of pulse protein concentrates and isolates. FASEB J. 2016;30(1_suppl.):421-6.

19. AACC International Method 22-40.01. Measurement of trypsin inhibitor activity of soy products-Spectrophotometric method. St. Paul, MN, USA: AACC International; 2006.

20. Mondor M, Aksay S, Drolet H, Roufik S, Farnworth E, Boye Jl. Influence of processing on composition and antinutritional factors of chickpea protein concentrates produced by isoelectric precipitation and ultrafiltration. Innov Food Sci Emerg Technol. 2009;10(3):342-47. https://doi.org/10.1016/j.ifset.2009.01.007

21. Makkar HPS, Siddhuraju S, Becker K. Plant secondary metabolites. In: Methods in molecular biology, vol 393. Totowa, NJ, USA: Humana Press; 2007. pp. 1-9. https://dpo.org/10.1007/978-1-59745-425-4

22. Waterman PG, Mole S. Analysis of phenolic plant metabolites. Oxford, UK: Wiley-Blackwell; 1994.

23. Makkar HP, Blümmel M, Borowy NK, Becker K. Gravimetric determination of tannins and their correlations with chemical and protein precipitation methods. J Sci Food Agric. 1993;61(2):161-65. https://doi.org/10.1002/jsfa.2740610205

24. White JA, Hart RJ, Fry JC. An evaluation of the waters pico-tag system for the amino-acid analysis of food materials. J Anal Methods Chem. 1986;8(4):170-7. https://doi.org/10.1155/S1463924686000330

25. Landry J, Delhaye S. Determination of tryptophan in feedstuffs: Comparison of sodium hydroxide and barium hydroxide as hydrolysis agents. Food Chem. 1994;49(1):95-7. https://doi.org/10.1016/0308-8146(94)90238-0

26. AOAC Official Method 988.15. Tryptophan in foods and food and feed ingredients, ion exchange chromatography method. Washington, DC, USA: AOAC International; 1995.

27. FAO/WHO/UNU. Energy and protein requirements: Report of a joint FAO/WHO/UNU expert consultation. WHO Tech Rep Ser 724. Geneva, Switzerland: Food and Agriculture Or- ganization of the United Nations and World Health Organization (FAO/WHO); 1985. Available from: http://www.who. int/iris/handle/10665/39527.

28. Hsu HW, Vavak DL, Satterlee LD, Miller GA. A multienzyme technique for estimating protein digestibility. J Food Sci. 1977;42(5):1269-73.

https://doi.org/10.1111/j.1365-2621.1977.tb14476.x

29. Tinus T, Damour M, van Riel V, Sopade PA. Particle sizestarch-protein digestibility relationships in cowpea (Vigna unguiculata). J Food Eng. 2012;113(2):254-64.

https://doi.org/10.1016/j.jfoodeng.2012.05.041

30. Systat v. 10 software. Systat Software Inc., San Jose, CA, USA; 2001.

31. Hahn DH, Rooney LW, Earp CF. Tannins and phenols of sorghum. Cereal Food World. 1984;29(12):776-9.

32. Gupta YP. Anti-nutritional and toxic factors in food legumes: A review. Plant Foods Hum Nutr. 1987;37(3):201-28. https://doi.org/10.1007/BF01091786

33. Oomah BD, Caspar F, Malcolmson LJ, Bellido AS. Phenolics and antioxidant activity of lentil and pea hulls. Food Res Int. 2011;44(1):436-41. https://doi.org/10.1016/j.foodres.2010.09.027

34. Wang X, Warkentin TD, Briggs CJ, Oomah BD, Campbell CG, Woods S. Trypsin inhibitor activity in field pea (Pisum sativum L.) and grass pea (Lathyrus sativus L.). J Agric Food Chem. 1998;46(7):2620-3. https://doi.org/10.1021/jf971007b

35. Starzyńska-Janiszewska A, Stodolak B. Effect of inoculated lactic acid fermentation on antinutritional and antiradical properties of grass pea (Lathyrus sativus 'Krab') flour. Pol J Food Nutr Sci. 2011;61(4):245-9. https://doi.org/10.2478/v10222-011-0027-3

36. Coda R, Melama L, Rizzello CG, Curiel JA, Sibakov J, Holopainen $U$, et al. Effect of air classification and fermentation by Lactobacillus plantarum VTT E-133328 on faba bean (Vicia faba L.) flour nutritional properties. Int J Food Microbiol. 2015;193:34-42. https://doi.org/10.1016/j.jfoodmicro.2014.10.012

37. Dueñas M, Fernández D, Hernández T, Estrella I, Muñoz R. Bioactive phenolic compounds of cowpeas (Vigna sinensis L). Modifications by fermentation with natural microflora and with Lactobacillus plantarum ATCC 14917. J Sci Food Agric. 2005;85(2):297-304.

https://doi.org/10.1002/jsfa.1924

38. McCue PP, Shetty K. Phenolic antioxidant mobilization during yogurt production from soymilk using kefir cultures. Process Biochem. 2005;40(5):1791-97. https://doi.org/10.1016/j.procbio.2004.06.067

39. Fernandez-Orozco R, Frias J, Muñoz R, Zielinski H, Piskula MK, Kozlowska $\mathrm{H}$, Vidal-Valverde C. Fermentation as a bio-process to obtain functional soybean flours. J Agric Food Chem. 2007;55(22):8972-9. https://doi.org/10.1021/jf071823b 
40. Limón RI, Peñas E, Torino MI, Martínez-Villaluenga C, Dueñas M, Frias J. Fermentation enhances the content of bioactive compounds in kidney bean extracts. Food Chem. 2015;172:343-52.

https://doi.org/10.1016/j.foodchem.2014.09.084

41. Osawa R, Kuroiso K, Goto S, Shimizu A. Isolation of tannin-degrading lactobacilli from humans and fermented foods. Appl Environ Microbiol. 2000;66(7):3093-97. https://doi.org/10.1128/AEM.66.7.3093-3097.2000

42. Rodríguez H, Curiel JA, Landete JM, de las Rivas B, de Felipe FL, Gómez-Cordovés C, et al. Food phenolics and lactic acid bacteria. Int J Food Microbiol. 2009;132(2-3):79-90.

https://doi.org/10.1016/j.ijfoodmicro.2009.03.025

43. Stodolak B, Starzyńska-Janiszewska A. The influence of tempeh fermentation and conventional cooking on anti-nutrient level and protein bioavailability (in vitro test) of grasspea seeds. J Sci Food Agric. 2008;88(13):2265-70. https://doi.org/10.1002/jsfa.3341

44. Sreekumar R, Al-Attabi Z, Deeth HC, Turner MS. Volatile sulfur compounds produced by probiotic bacteria in the presence of cysteine or methionine. Lett Appl Microbiol. 2009;48(6):777-82.

https://doi.org/10.1111/j.1472-765X.2009.02610.x 